DOI: 10.34015/2523-4552.2020.1.21

УдК $343.28+343.29$

Бурбела Ю. С.,

здобувач кафедри кримінального права

Національної академії внутрішніх справ ORCID: 0000-0002-3565-6574

\title{
ДОБРОВІЛЬНЕ ВІДШКОДУВАННЯ ЗАВДАНОГО ЗБИТКУ АБО УСУНЕННЯ ЗАПОДІЯНОЇ ШКОДИ: ПРОБЛЕМИ ПОНЯТІЙНО-КАТЕГОРІАЛЬНОГО АПАРАТУ
}

У статті проаналізовано актуальні проблеми застосування термінів «шкода», «збиток», «відшкодування», «усунення», «компенсація», «загладжування» в контексті заохочувальних кримінально-правових норм, що стосуються добровільного відшкодування завданого збитку або усунення заподіяної шкоди. Визначено переваги та недоліки їх застосування у КК України. Сформульовано пропозиції щодо уніфікації зазначених термінів з метою вироблення єдиних підходів щодо узгодженого їх застосування в кримінальному, кримінально-процесуальному та цивільному законодавстві.

Ключові слова: збиток; шкода; реституція; відшкодування завданого збитку; усунення заподіяної шкоди; потерпілий.

В статье проанализированы актуальные проблемы применения терминов «вред», «ущерб», «возмещение», «устранение», «компенсация», «заглаживания» в контексте поощрительных уголовно-правовых норм, касающихся добровольного возмещения нанесенного ущерба или устранение причиненного вреда. Определены преимущества и недостатки их применения в УК Украины. Сформулированы предложения по унификации указанных терминов с целью выработки единых подходов согласованного их применения в уголовном, уголовно-процессуальном и гражданском законодательстве.

Ключевые слова: ущерб; вред; реституция; возмещения нанесенного ущерба; устранение причиненного вреда; пострадавший.

Постановка проблеми. Розбудова України як незалежної та демократичної держави європейського зразка потребує створення ефективних механізмів захисту прав і свобод людини та громадянина від злочинних посягань, які досить часто знаходять свій прояв у заподіянні їм фізичної, моральної та матеріальної шкоди.

У системі таких механізмів важливе місце відводиться кримінально-правовому забезпеченню добро- вільного відшкодування шкоди, завданої злочином. У КК України існує ціла система норм, що визначають підстави застосування заходів кримінально-правового заохочення $\mathrm{y}$ випадку добровільного відшкодування завданого збитку або усунення заподіяної шкоди.

Нині застосування зазначених норм ускладнене низкою обставин, зокрема відсутністю базових термінів (шкода, збитки, відшкодування, усунення); застосуванням різної те- 
рмінології у різних галузях законодавства для позначення шкоди чи збитків, завданих злочином (кримінальному, кримінальному процесуальному, цивільному) тощо.

Про недостатню ефективність застосування механізму добровільного відшкодування завданого збитку або усунення заподіяної шкоди певною мірою свідчать і статистичні дані. Якщо у 2019 р. встановлена сума матеріальних збитків у провадженнях за якими закінчені розслідування складала 46138955,54 (46 млрд 138 млн 955 тис. грн), то відшкодовано збитків за вказаний період було лише на суму 2660453,24 (2 млрд 660 млн 453 тис. грн), тобто лише $17,3 \%$ [1].

Постановка завдання. 3 огляду на зазначене виникла необхідність в удосконаленні понятійнокатегоріального апарату, який застосовується під час добровільного відшкодування завданого збитку або усунення заподіяної шкоди, та приведення його у відповідність до кращих національних та зарубіжних стандартів з метою підвищення ефективності застосування відповідних кримінально-правових норм.

Аналіз останніх досліджень і публікацій. Вагомим внеском у розроблення питань добровільного відшкодування завданих збитків або усунення заподіяної шкоди $є$ дослідження українських учених Ю. В. Бауліна, А. М. Бойка, I. А. Вартилецької, А. А. Вознюка, М. Є. Григор'євої, В. К. Грищука, О.П.Гороха, О. О. Дудорова, О. О. Житного, Т. І. Іванюк, О. О. Книженко, В. О. Навроцького, Є. С. Назимка, Є. О. Письменського А. В. Савченка, А. А. Стрижевської, П. Л. Фріса, Г. О. Усатого, М. І. Хавронюка, П. В. Хряпінсько- го С. Д. Шапченка, С. С. Яценка,

А. М. Ященка та ін.

Одержані вченими висновки становлять потужний фундамент для розв'язання проблем кримінально-правового забезпечення добровільного відшкодування завданих збитків або усунення заподіяної шкоди. Водночас вивчення судової практики свідчить про те, що норми про добровільне відшкодування завданого збитку або усунення заподіяної шкоди застосовуються не завжди правильно та достатньо ефективно, зокрема через різне їх тлумачення як судовими, так і правоохоронними органами.

Виклад основного матеріалу. Застосування кримінально-правових норм, що регулюють добровільне відшкодування завданого збитку або усунення заподіяної шкоди у кримінальному законодавстві України нині ускладнене низкою проблемних питань.

Насамперед йдеться про відсутність єдиної, усталеної базової термінології (вона стосується в першу чергу таких понять як шкода, збитки, відшкодування, усунення). Це перешкоджає однозначному застосуванню відповідних заохочувальних кримінально-правових норм та призводить в окремих випадках до скасування судових рішень у зв'язку з неправильним застосуванням судом норм матеріального права.

Норми, що регулюють добровільне відшкодування завданого збитку або усунення заподіяної шкоди мають міжгалузевий характер - функціонують не лише у кримінальному, але й кримінальному процесуальному, цивільному, адміністративному та інших галузях законодавства. Причому міждисциплінарною про- 
блемою є застосування різної термінології у різних галузях законодавства для позначення шкоди чи збитків, завданих злочином.

Ні у кримінальному, ні у кримінальному процесуальному законодавстві поняття «шкода» і «збиток» не визначено. Поряд з цим у КПК України вживаються поняття «матеріальні збитки», «збитки внаслідок вчинення кримінального правопорушення», «шкода немайнового характеру», «шкода довкіллю», «шкода, заподіяна кримінальним правопорушенням» тощо [2]. Водночас у ЦК України застосовано поняття «збитки» і «шкода» [3].

у тлумачному словнику під збитками розуміються матеріальні втрати [4, с. 441]. 3 огляду на це слід розкрити терміни «матеріальний» та «витрати». Матеріальний - стосовно до матерії; який існує незалежно від свідомості; протилежне духовний; який має відчутну форму; речовий, предметний; пов'язаний 3 володінням певною власністю, 3 прибутками, заробітком, грошима; матеріальний добробут; призначений для зберігання матеріалів [4, c. 651]. Натомість утрата (втрата) дія, внаслідок якої хтось лишається без кого-, чого-небудь, втрачає когось, щось; той (те), хто (що) втрачений (втрачене); що-небудь загублене, вкрадене, розбите і т. ін.; щонебудь утрачене, загублене, украдене, розбите; зменшення кількості чого-небудь; марне, без користі витрачання чого-небудь; гроші, кошти, витрачені на що-небудь; збитки [4, c. 1521]. Виходячи із семантичного значення відповідних термінів під збитками, які завдаються в результаті вчинення злочину слід розуміти втрату внаслідок злочину речей, предметів, якими володіє потерпілий, включаючи його кошти, а також витрачання коштів на ліквідацію наслідків вчинення злочину.

Натомість термін «шкода» має декілька значень: 1) матеріальні втрати; збитки; збитки, втрати, неприємності тощо, що $є$ наслідком яких-небудь дій, учинків; 2) те саме, що біда; 3) те саме, що пустун; 4) те саме, що вина; 5) співчуття до кого-, чого-небудь; жаль; 6) про почуття прикрості 3 приводу втрати чогонебудь; 7) про небажання витрачати, віддавати що-небудь, позбуватися чогось; 8) марно, даремно [4, с. 1624]. Очевидно, що для потреб цього дослідження найбільше значення має перше та друге значення терміну «шкода». Виходячи 3 цього можна стверджувати, що шкода від злочину може полягати у збитках, а також інших втратах і неприємностях, що виникають у зв'язку з вчиненням цього суспільно небезпечного діяння.

За результатами семантичного аналізу термінів шкода і збиток можна зробити висновок, що вони співвідносяться між собою як частина i ціле, де збитки $є$ частиною, а шкода цілим. Відтак, шкода включає збитки. Водночас можна зробити і другий висновок про те, що шкода не зводиться виключно до матеріальних втрат, тобто до збитків. Шкода окрім матеріальних втрат може включати також інші втрати та неприємності, які очевидно можуть утворювати моральну та фізичну шкоду.

Щодо співвідношення понять «шкода» і «збитки» в теорії кримінального права слід відмітити, що більшість вчених їх розмежовує. Наприклад, 0. О. Житний робить висновок, що поняття «збитки» законода- 
вець вважає підпорядкованим щодо поняття «шкода», тобто збитки $\epsilon$ лише різновидом шкоди [5, с. 123]. I. I. Митрофанов і Т. В. Гайкова стверджують, що поняття «шкода» у законодавстві України є ширшим за поняття «збитки». Шкода може бути відшкодована і в грошовій формі, і в натурі, а збитки - лише в грошовій формі, тобто шкода завжди включає в себе збитки [6, с. 199].

Розглянувши позиції вчених слід зазначити, що поняття «шкода» $\mathrm{i}$ «збиток» не співпадають. Ці кримінально-правові категорії не можна вважати і синонімічними. Поняття шкода - охоплює збитки. Натомість збитки є різновидом шкоди.

У КК України вживаються різні конструкції для позначення збитків і шкоди як у Загальній, так і Особливій частині КК України. Наприклад, «істотна шкода здоров'ю потерпілого» (ст. 137 КК України), «матеріальні збитки» (ст. 182 КК України), «матеріальна шкода» (ст. 206 КК України), «майнова шкода», «прямі збитки» (ст. 265 КК України) тощо.

Аналіз положень закону про кримінальну відповідальність дозволяє виокремити типові помилки, які допускає законодавець у використанні понять «збитки» і «шкода».

1. Одночасне вживання в одному й тому ж законодавчому положенні обох термінів як синонімів. Наприклад, відповідно до примітки 1 до ст. 232-1 КК України значним розміром (значним збитком, значною шкодою) у цій статті вважається розмір (збиток, шкода), який в п'ятсот і більше разів перевищує неоподатковуваний мінімум доходів громадян. У цьому випадку законодавець і шкоду і збиток визначає у грошовому еквіваленті і повністю ототожнює їх, від- так виникає питання який в цьому сенс?

2. Визначення шкоди через збитки. Наприклад, у примітці 2 до ст.185 КК України законодавець значну шкоду визначає із врахуванням матеріального становища потерпілого та якщо йому спричинені збитки на суму від ста до двохсот п'ятдесяти неоподатковуваних мінімумів доходів громадян. Знову ж виникає питання, навіщо тут вживати обидва терміни для позначення одного й того ж явища?

3. Застосування необгрунтовано великої варіації різновидів шкоди і збитків, позначаючи їх в окремих випадках за допомогою оціночних конструкцій. У КК України види шкоди визначають по-різному, зокрема як істотну, тяжку, значну, у великому, особливо великому розмірі. Водночас їх значення у різних складах злочинів різне.

Таким чином, незважаючи на те, що у законі про кримінальну відповідальність розмежовуються поняття «шкода» і «збиток», подекуди їх застосування слід визнати необгрунтованим, через ототожнення цих кримінально-правових категорій, паралельне їх вживання та різнобічне тлумачення.

Тому необхідно уніфікувати застосовувану у законі про кримінальну відповідальність термінологію, що стосується визначення різновидів збитків і шкоди з метою як забезпечення правильної кваліфікації злочинів, так і оптимізації процесу їх добровільного відшкодування та усунення.

Не можна ототожнювати збитки і шкоду, якщо законодавець вживає їх паралельно. Якщо у кримінально-правовій нормі йдеться про 
збиток, то відшкодовувати слід саме його. Якщо ж вживається шкода, то вона може бути як матеріальною, так і фізичною та моральною.

Категорії «збитки» і «шкода» $\epsilon$ основою подальших досліджень понятійно-категоріального апарату, що застосовується в механізмі добровільного відшкодування завданого збитку або усунення заподіяної шкоди. Адже існують проблеми у позначенні окремих видів шкоди та визначенні їх меж (наприклад, екологічної шкоди, шкода довкіллю тощо). На ці проблеми неодноразово звертали увагу вчені [7].

Добровільне відшкодування завданого збитку або усунення заподіяної шкоди визначаються законодавцем 3 використанням термінів «відшкодування» та «усунення». 3 огляду на зазначене слід розкрити їх зміст та взаємозв'язок з метою вироблення єдиної практики застосування відповідних заохочувальних кримінально-правових норм. Необхідно також звернути увагу на коректність їх застосування та можливі перспективи удосконалення.

У тлумачному словнику відшкодування має такі значення: 1) дія за значенням відшкодувати; 2) те, що повертається комусь за зроблену шкоду, витрати [4, с. 185]. Натомість усунення означає: 1) доводити щонебудь до зникнення, припиняти існування; ліквідувати; виключати, викидати звідкись; 2) так чи інакше позбавлятися когось (відсторонити від якоїсь діяльності, справи, звільняти 3 роботи і т. ін.); позбуватися [4, с. 1518].

Аналіз семантичного значення терміну «відшкодування» свідчить про те, що він стосується шкоди або витрат і полягає в поверненні чо- гось за зроблену шкоду, чи надання чогось взамін замість втраченого, а також поповнення витрат, збитків чимсь іншим. 3 огляду на таке його багатогранне значення цей термін може застосовуватися як у відношенні шкоди, так і збитків.

Водночас термін «усунення» стосується лише зникнення, припинення існування, ліквідування, позбавлення. Відтак, він найбільше підходить до збитків, оскільки їх можна ліквідувати, наприклад, шляхом повернення певної речі, її заміни на іншу чи відновлення попереднього стану. Однак термін «усунення» не може стосуватися усіх видів шкоди, зокрема фізичної та моральної, адже такі види шкоди не завжди зникають чи припиняють своє існування. У зв'язку з цим застосування терміну «усунення» по відношенню до шкоди $є$ необгрунтованим. Усунення більше стосується збитків або виключно матеріальної шкоди. Говорити ж про усунення моральної чи фізичної шкоди некоректно, для таких ситуацій більше підходить термін відшкодування.

Невипадково окремі вчені зазначають про відшкодування шкоди $[8$, с. $183 ; 9$, с. 9, с. $113 ; 10]$, а не про ії усунення. Про відшкодування шкоди йдеться і в судових рішеннях [11]. Термін «відшкодування» вживається і в КПК України.

Натомість законодавець чітко асоціює поняття «відшкодування» зі збитками, а «усунення» зі шкодою. Це певною мірою суперечить семантичному аналізу термінів «відшкодування» та «усунення». Тому й не дивно, що незважаючи на це в судовій практиці його використовують як 3 поняттям «збитки»[12], так і «шкода» [13]. 
3 огляду на вживання в одній конструкції термінів «усунення» та «відшкодування» варто акцентувати на їх відмінності. Очевидно, що ідея закладалася в тому, що усунення стосується не будь-якого способу відшкодування шкоди, а лише такого, який передбачає особисту поведінку особи, яка вчинила злочин, спрямовану на ліквідацію шкоди власними силами, тобто в натурі. Відповідно до положень ч. 4 ст. 22 ЦК це означає передання речі того ж роду та тієї ж якості, полагодження пошкодженої речі тощо [3]. Таким чином, усунення завданої шкоди $€$ лише одним із способів її відшкодування. У зв'язку з цим виникає закономірне питання навіщо його відокремлювати серед інших способів. Він не так часто зустрічається у судовій практиці і стосується переважно пошкоджених речей (пошкодженого майна).

Нині для маневру в арсеналі правових інструментів правоохоронці можуть враховувати й інші способи відшкодування шкоди, завданої злочином, зокрема передачу потерпілому замість знищеної іншої нової речі, компенсування фізичної чи моральної шкоди потерпілому. Водночас виокремлювати кожен спосіб відшкодування шкоди, завданої злочином, в якості самостійного елемента конструкції заохочувальної норм не має особливої потреби.

3 огляду на це можна зробити висновок про необгрунтованість застосування терміну «усунення» в контексті саме шкоди. Взамін цього термін «відшкодування» може бути застосований як до шкоди, так і збитків.

Окрім термінів «відшкодування» та «усунення» в контексті дослі- джуваної конструкції позитивних післязлочинних дій пропонується використовувати й інші терміни, зокрема «компенсація», «згладжування», а за кордоном досить поширеним $€$ термін «реституція» $[14 ; 15]$.

В тлумачному словнику компенсувати означає давати компенсацію за що-небудь; відшкодовувати; поповнювати, вирівнювати, зрівноважувати що-небудь [4, с. 560]. Цікавим $\epsilon$ той факт, що компенсація виходячи із семантичного значення цього терміну включає інший термін «відшкодування». Найчастіше термін «компенсація» вживають у відношенні моральної шкоди. Існує навіть пропозиція в контексті моральної шкоди замінити термін «відшкодування» на «компенсація» [16, с. 910]. Хоча очевидним $\epsilon$ той факт, що цей термін, з огляду на його семантичне значення, можна застосовувати в контексті усіх видів шкоди.

У КПК України вживається конструкція «відшкодування (компенсація) шкоди». $Є$ навіть окрема глава - 9 «Відшкодування (компенсація) шкоди у кримінальному провадженні, цивільний позов». Аналогічна конструкція вживається і в ЦК України, наприклад в ст. 1177 «Відшкодування (компенсація) шкоди фізичній особі, яка потерпіла від кримінального правопорушення», хоча в самій статті в частині першій вживається поняття «відшкодування», а в частині другій - «компенсація». 3 огляду на це можна стверджувати, що у цивільному законодавстві зазначені терміни вживаються як синоніми. Водночас в КПК України $\epsilon$ певна відмінність: компенсація стосується випадків відшкодування за рахунок Державного бюджету України. У більшості інших норм як ЦК та 
КПК України застосовується термін «відшкодування» як у контексті «шкоди», так і «збитків». 3 огляду на це логічною може бути пропозиція вживати термін компенсація виключно для випадків відшкодування шкоди за рахунок Державного бюджету України, а для випадків відшкодування шкоди особою, яка її завдала в результаті вчинення злочину - застосовувати термін «відшкодування».

Окремі вчені виділяють ще й термін загладжування шкоди, заподіяної злочином [17, с. 184]. Термін «загладжувати» має такі значення: 1) робити гладким, вирівнювати, розправляти що-небудь нерівне, кошлате, зім'яте і т. ін.; 2) пом'якшувати враження від поганої поведінки, грубого вчинку і т. ін. [4, с. 384]. варто погодитися 3 тим, що зазначений термін можна вживати у тому випадку, якщо потерпілому заподіяна фізична або моральна шкода, ліквідувати, позбутися чи припинити ії навряд чи можливо [17, c. 170]. Вцілому не заперечуючи аргументів на користь переваг застосування цього терміну «загладжування заподіяної шкоди» варто відмітити його.

Однак, хоча термін «загладжування» має переваги перед терміном «усунення», однак слід наголосити на тому, що він не має особливих перевагах перед терміном «відшкодування», який широко застосовується в різних галузях законодавства.

На підставі вищезазначеного вважаємо, що найбільш прийнятним терміном для позначення відповідної позитивної післязлочинної поведінки є термін «відшкодування».

Висновки. Незважаючи на те, що терміни «шкода» $\mathrm{i}$ «збиток» у сво- ïx значеннях не співпадають у науці кримінального права та практиці застосування кримінального законодавства існують труднощі у їх застосуванні, пов'язані із розмежуванням та неоднозначним тлумаченням.

Вирішення цієї проблеми вбачається одним із таких способів: 1) використання для потреб кримінального права значення цих термінів, що використовується у цивільному та іншому законодавстві; 2) закріплення їх визначення у законі про кримінальну відповідальність. У будь-якому випадку ці терміни слід уніфікувати, надавши їм легального визначення.

Аналіз положень закону про кримінальну відповідальність дозволяє виокремити типові помилки, які допускає законодавець у використанні понять «збитки» і «шкода»: 1) одночасне вживання в одному й тому ж положенні обох термінів як синонімічні; 2) визначення шкоди через збитки; 3) застосування необгрунтовано великої варіації різновидів шкоди і збитків, позначаючи їх в окремих випадках за допомогою оціночних конструкцій.

Аналіз семантичного значення термінів «відшкодування» та «усунення» в контексті таких категорій як «збитки» та «шкода» свідчить про необгрунтованість їх вживання у конструкції «добровільне відшкодування завданого збитку або усунення заподіяної шкоди». Оскільки добровільне усунення заподіяної шкоди $є$ лише одним і не найбільш поширеним способом іiі відшкодування немає необхідності у його виокремленні.

На підставі вищезазначеного вважаємо, що найбільш прийнятним терміном для позначення відповід- 
ної позитивної післязлочинної поведінки $є$ термін «відшкодування». Саме його слід застосовувати у кримінальному законодавстві.

Під відшкодуванням завданої шкоди слід розуміти усунення, компенсацію, згладжування різних її видів. Це дії спрямовані на ліквідацію наслідків злочину, відновлення попереднього стану речей або приведення їх до придатних для користування характеристик, передачу потерпілому замість знищеної іншої нової речі, компенсування фізичної чи моральної шкоди.

3 урахуванням зазначених положень слід удосконалити юридичні конструкції добровільного відшкодування завданого збитку або усунення заподіяної шкоди у кримінально-правових нормах, що стосуються пом'якшення покарання, звільнення від кримінальної відповідальності, покарання та його відбування.

\section{Список використаних джерел}

1. Статистична звітність Генеральної прокуратури України за 2019 p. URL: https://old.gp.gov.ua/ua/stst2011.html?dir_id=104402 (дата звернення 25.02.2020).

2. Кримінальний процесуальний кодекс України від 13 квітня 2012 р. № 4651VI. URL: http://zakon5.rada.gov.ua/laws/show/4651-17 (дата звернення 25.02.2020).

3. Цивільний кодекс України від 16 січня 2003 p. № 435-IV. URL: http://zakon5.rada.gov.ua/laws/show/435-15 (дата звернення 25.02.2020).

4. Великий тлумачний словник сучасної української мови / Уклад. і голов. ред. В. Т. Бусел. Ірпінь: ВТФ «Перун», 2009. 1736 с.

5. Житний 0. О. Звільнення від кримінальної відповідальності у зв'язку з дійовим каяттям: дис. ...канд. юрид. наук: 12.00.08. Харків, 2003. 210 с.

6. Митрофанов I. I., Гайкова Т. В. «Шкода» та «збитки»: співвідношення понять. Вісник КрНУ ім. Михайла Остроградського. Вип. 3/2012 (74). С. 196-200.

7. Gerasimenko A. Environmental Damage in the Criminal Trial of Russia. In «New Silk Road: Business Cooperation and Prospective of Economic Development». Atlantis Press. 2020. March.pp. 144-147. DOI: https://doi.org/10.2991/aebmr.k.200324.027.

8. Вознюк А. А. Спеціальні види звільнення від кримінальної відповідальності учасників організованих злочинних об'єднань: монографія. Київ: Нац. акад. внутр. справ, 2015. 236 с.

9. Вознюк А. А., Назимко Є. С. Проблемні питання законодавчої регламентації заохочувальних кримінально-правових норм, що стосуються відшкодування шкоди, завданої державі. Вісник Луганського державного університету внутрішніх справ імені Е. О. Дідоренка. 2013. № 1(62). С. 119-120.

10. Відшкодування потерпілому шкоди, завданої кримінальним правопорушенням: навч. посіб. [Текст] / [А. А. Вознюк, Д. О. Алєксєєва-Процюк, С. С. Бичкова, Бурбела Ю. С. та ін.]; за заг. ред. д-ра юрид. наук. проф. С. С. Чернявського. Київ: Нац. акад. внутр. справ, 2017. 136 с.

11. Вирок Тернівського міського суду Дніпропетровської області від 02 берез. 2020 р. у справі № 194/2061/19. Провадження № 1-кп/194/19/20. URL: http://reyestr.court.gov.ua/Review/87932219 (дата звернення 05.03.2020).

12. Ухвала Маньківського районного суду Черкаської області від 26 груд. 2019 р. у с справіа № 701/1424/19. Провадження № 1-кп/701/137/19. URL: http://wwwreyestr.court.gov.ua/Review/86638507 (дата звернення 25.02.2020).

13. Ухвала Гайсинського районного суду Вінницької області від 19 груд. 2019 р. у справі № 129/2547/19. Провадження № 1-кп/129/512/2019. URL: http://www.reyestr.court.gov.ua/Review/86439135 (дата звернення 25.02.2020). 
14. Kiefer R. P., Worthington E. L., Wenzel M., Woodyatt L., \& Berry J. W. Apology and Restitution in a Role-play Restorative Justice Experiment: Multiple Perspectives, Multiple Measures. Journal of Psychology and Theology. 2020. DOI: https://doi.org/ 10.1177/0091647120911114.

15. Pasaribu R. T. H. Fulfillment of Restitution Right of Human Trafficking Crime Victim through Restorative Justice Approach in Criminal Justice System in Indonesia. International Journal of Multicultural and Multireligious Understanding. 2020. № 7(2). P. 504-518. DOI: http://dx.doi.org/10.18415/ijmmu.v7i2.1521.

16. Майстер I. П. Компенсація моральної шкоди як спосіб захисту особистих немайнових прав фізичної особи: автореф. дис. ... канд. юрид. наук: 12.00.03. Київ: Генеральна прокуратура України, Нац. акад. прокуратури України, 2015. 20 с.

17. Григор'єва М. Є. Звільнення особи від кримінальної відповідальності у зв'язку з їі дійовим каяттям: дис. ...канд. юрид. наук: 12.00.08. Харків, 2007. 204 с.

\section{References}

Velykyj tlumachnyj slovnyk suchasnoyi ukrayins `koyi movy (2009) / Uklad. i golov. red. Busel, V. T. Irpin`: VTF «Perun» [in Ukrainian].

Zhytnyj, 0. 0. (2003). Zvil`nennya vid kryminal`noyi vidpovidal’nosti u zvyazku z dijovym kayattyam: Extended abstract of candidate's thesis. Harkiv [in Ukrainian].

Mytrofanov, I. I., Gajkova, T. V. (2012). «Shkoda» ta «zbytky»: spivvidnoshennya ponyat'. Visny`k KrNU im. Myxajla Ostrograds 'kogo, 3/(74), 196-200 [in Ukrainian].

Gerasimenko, A. (2020). Environmental Damage in the Criminal Trial of Russia. In «New Silk Road: Business Cooperation and Prospective of Economic Development». Atlantis Press, 144-147. DOI: https://doi.org/10.2991/aebmr.k.200324.027.

Voznyuk, A. A. (2015). Special'ni vydy’ zvil'nennya vid kryminal noyi vidpovidal 'nosti uchasnykiv organizovanyx zlochynnyx obyednan'. Kyiv: Nacz. akad. vnutr. sprav [in Ukrainian].

Voznyuk, A. A., Nazymko, Ye. S. (2013). Problemni pytannya zakonodavchoyi reglamentaciyi zaoxochuval'nyx kryminal’no-pravovyx norm, shho stosuyut'sya vidshkoduvannya shkody, zavdanoyi derzhavi. Visnyk Luganskogo derzhavnogo universytetu vnutrishnix sprav imeni E. O. Didorenka, 1(62), 119-120 [in Ukrainian].

Voznyuk, A. A., Alyeksyeyeva-Procyuk, D. O., Bychkova, S. S., Burbela, Yu. S. ta in. (2017). Vidshkoduvannya poterpilomu shkody, zavdanoyi kryminal’nym pravoporushennyam: navch. posib.; za zag. red. d-ra yury`d. nauk. prof. S. S. Chernyavs`kogo. Kyiv: Nacz. akad. vnutr. sprav [in Ukrainian].

Kiefer, R. P., Worthington, E. L., Wenzel, M., Woodyatt, L., \& Berry, J. W. (2020). Apology and Restitution in a Role-play Restorative Justice Experiment: Multiple Perspectives, Multiple Measures. Journal of Psychology and Theology. DOI: https://doi.org/10.1177/0091647120911114.

Pasaribu, R. T. H. (2020). Fulfillment of Restitution Right of Human Trafficking Crime Victim through Restorative Justice Approach in Criminal Justice System in Indonesia. International Journal of Multicultural and Multireligious Understanding, 7 (2), 504-518. DOI: http://dx.doi.org/10.18415/ijmmu.v7i2.1521.

Majster, I. P. (2015). Kompensaciya moral’noyi shkody yak sposib zaxystu osobystyx nemajnovyx prav fizychnoyi osoby: Extended abstract of candidate's thesis, Kyiv: General'na prokuratura Ukrayiny', Nacz. akad. prokuratury` Ukrayiny, 20 [in Ukrainian].

Grygor'yeva, M. Ye. (2007). Zvil`nennya osoby vid kryminal’noyi vidpovidal nosti u zvyazku z yiyi dijovym kayattyam: Extended abstract of candidate's thesis. Harkiv, 204 [in Ukrainian]. 
Yu. Burbela, Researcher of the Department of Criminal Law of the National Academy of Internal Affairs

ORCID: 0000-0002-3565-6574

\section{Voluntary compensation of the caused \\ damage or elimination of the damage caused: the problem of conceptual-categorical apparatus}

The article analyzes actual problems of the application of the terms «loss» «damage», «refund», «elimination», «compensation», «smoothing» in the context of encouraging criminal-legal norms on voluntary compensation of the caused damage or elimination of the damage caused.

It argues that the interdisciplinary nature of the legal categories of «damage» and «loss» requires their harmonization with the aim of developing common approaches regarding the harmonized application in the criminal, criminal-procedural and civil legislation.

It was established that despite the fact that the criminal law delineates the concept of «damage» and «loss» in some places, their use should be recognized ungrounded, through the identification of these criminal-legal categories and improper use.

As a result of the analysis of the provisions of the law on criminal liability, the typical mistakes that the legislator makes in using the terms «damage» and «loss» are highlighted, as well as ways of their correction are suggested.

Determined the advantages and disadvantages of the application of the criminal code of the terms «loss», «damage», «refund», «elimination», «compensation», «smoothing». Formulated proposals on the standardization of the deadlines, and optimization of the legal construction of «voluntary compensation of the caused damage or elimination of the caused harm» to the criminal legal provisions concerning mitigation of punishment, release from criminal liability and punishment and serving it.

Keywords: loss; damage; restitution; compensation for the loss caused; elimination of the damage caused; victim. 